\title{
Physicians' attitudes towards interaction with the pharmaceutical industry
}

\author{
F.D. Alosaimi, ${ }^{1}$ A. Al Kaabba,${ }^{2}$ M. Qadi, ${ }^{3}$ A. Albahlal, ${ }^{7}$ Y. Alabdulkarim, ${ }^{7}$ M. Alabduljabbar ${ }^{7}$ and F. Alqahtani ${ }^{7}$
}

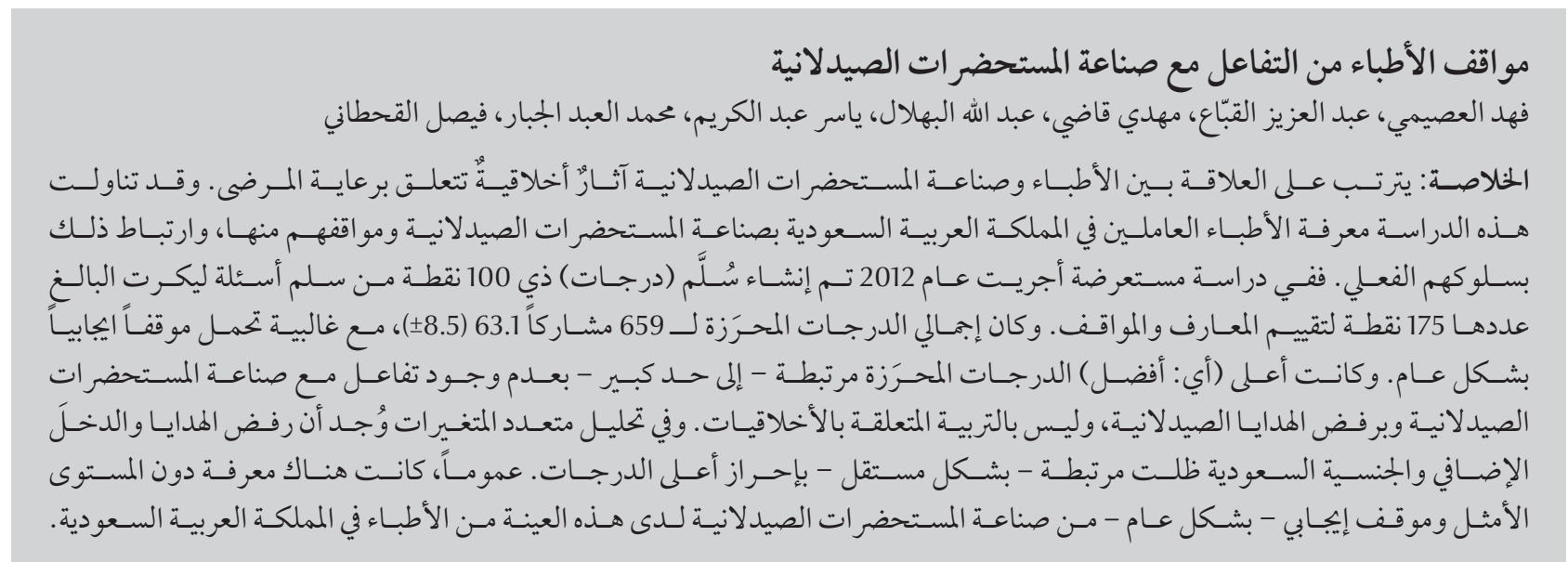

ABSTRACT The relationship between physicians and the pharmaceutical industry has ethical implications for patient care. This study examined knowledge and attitudes towards the pharmaceutical industry, and associations with actual behaviour, among physicians working in Saudi Arabia. In a cross-sectional study in 2012, a 100-point score was created from 17 5-point Likert-scale questions to assess knowledge and attitudes. The overall score of 659 participants was 63.1 (SD 8.5), with a majority holding a generally positive attitude. Higher (i.e. better) scores were significantly associated with a lack of interactions with the pharmaceutical industry and with refusal of gifts but not with education about ethics. In multivariate analysis, refusing gifts, additional income and Saudi nationality remained independently associated with higher scores. Overall, there was suboptimal knowledge and a generally positive attitude towards the pharmaceutical industry among the sample of physicians in Saudi Arabia.

\begin{abstract}
Attitudes des médecins par rapport à l'interaction avec l'industrie pharmaceutique
RÉSUMÉ Les relations entre les médecins et l'industrie pharmaceutique ont des implications éthiques pour les soins aux patients. La présente étude a examiné les connaissances et les attitudes envers l'industrie pharmaceutique, ainsi que les associations avec les comportements réels chez des médecins exerçant en Arabie saoudite. Dans une étude transversale menée en 2012, un score sur 100 a été créé à partir de 17 questions sur une échelle de Likert en 5 points visant à évaluer les connaissances et les attitudes. Le score global des 659 participants était de 63,1 (ET 8,5), la majorité ayant généralement une attitude positive. Les scores les plus élevés (c'est-à-dire les meilleurs scores) étaient nettement associés à une absence d'interactions avec l'industrie pharmaceutique et le refus de cadeaux, mais n'étaient pas liés à une formation sur l'éthique. À l'analyse multivariée, le refus de cadeaux, des revenus supplémentaires ainsi que la nationalité saoudienne étaient des facteurs indépendamment associés à des scores plus élevés. Globalement, les connaissances étaient sous-optimales et l'attitude envers l'industrie pharmaceutique était généralement positive au sein de l'échantillon de médecins répondeurs en Arabie saoudite.
\end{abstract}




\section{Introduction}

There is accumulating evidence from different parts of the world indicating that nearly all physicians maintain some sort of relationship with the pharmaceutical industry (1-3). This relationship may be seen as beneficial to patients, as physicians and the pharmaceutical industry have common interests in conducting research and developing new, safe and effective medications (4). On the other hand, the relationship may be seen as harmful to patients, due to the conflict of interest between the physician, whose primary interest is patients' welfare, and the pharmaceutical industry, which has a primary interest in maximizing profits for shareholders $(4,5)$. This raises numerous ethical questions about the appropriateness of physicians' accepting gifts, the degree of transparency and disclosure of received benefits, the impact on health-care costs, influences on health-care decisions, the effect on the research agenda and its results, and the impact on the physician-patient relationship (6-8).

The attitude of physicians towards their relationship with the pharmaceutical industry has been examined in a number of studies (9-11) and the possibility that such a relationship may influence physicians' clinical decisionmaking has been also examined (12). However, there are limited data linking physicians' knowledge and attitude with their own behaviour towards the pharmaceutical industry. Moreover, studies examining the attitude of physicians towards the relationship are completely lacking in Saudi Arabia. The objective of the current study was to examine knowledge and attitudes towards the pharmaceutical industry among physicians working in Saudi Arabia, including accepting gifts, ethical issues, influence on clinical decisions and accuracy of information provided. Additionally, the study aimed to examine the association of such knowledge and attitudes with physicians' own behaviour towards any sort of interaction with the pharmaceutical industry and accepting pharmaceutical company gifts.

\section{Methods}

\section{Study design and setting}

A cross-sectional study was carried between March and July 2012. The study obtained all required ethical approvals from the institutional review board at the Faculty of Medicine at King Saud University, Riyadh, Saudi Arabia.

Approximately $80 \%$ of the healthcare services in Saudi Arabia including prescriptions are provided free of charge by the government (13). The private sector provides fee-paid services and is considered a more easily accessible sector compared with the government sector. However, the cost is largely covered by private employers who are required by law to provide free insurance to their employees (13).

\section{Population}

The current study was conducted among physicians working in secondary- and tertiary-care hospitals in Saudi Arabia. All ranks of physicians of both medical and surgical specialties were included. Samples were recruited from 10 hospitals (both government and private) in the Central, Eastern, Western, Northern and Southern regions of Saudi Arabia. Medical students and other health-care workers were excluded. Physicians without patient care responsibilities were excluded.

We estimated that 631 participants were required to detect a $20 \%$ difference in attitude towards the pharmaceutical industry (for example, $50 \%$ versus $30 \%$ ) between 2 levels of a given characteristics (such as having or lacking medical education), at $95 \%$ confidence level and $80 \%$ power.

Because of the difficulty of getting rosters of working physicians for each hospital, we recruited the required sample size from the physicians available at the time of the study (convenience sample). We distributed 1000 questionnaire in both paper (75\%) and electronic (25\%) formats and obtained 663 responses. Four questionnaires were excluded due to lack of interaction questions, leaving 659 for analysis. Informed consent was obtained from all participants after explanation of the study objectives.

\section{Data collection tool}

A self-administrated questionnaire was developed and administered to all participants. It first asked about the sociodemographic, economic and occupational characteristics of the study participants. The questionnaire then assessed outcome variables, including history of any interaction with pharmaceutical sales representatives, the physician's acceptance of pharmaceutical company gifts and any ethics education received. Pharmaceutical company gifts in the current study were described in the questionnaire as stationery items, free drug samples, free meals, financial support to attend educational activities, funding for research and prepaid promotion cards/codes. The participants were asked to answer 17 questions to assess their knowledge and attitude towards gifts, medical ethics, influences on care decisions and the accuracy of information given by pharmaceutical sales representatives about new pharmaceutical medications. Ten of these questions were general and were answered by everyone, while 7 questions were answered only by those who had a history of actual interactions with pharmaceutical sales representatives. The content of the questionnaire was validated by a multidisciplinary committee covering ethics, psychiatry, pharmacy and epidemiology. The questionnaire was then piloted on a small number of participants $(n=16)$ before widespread distribution. The wording and suggested answers were modified for some questions based on the feedback from the pilot sample. The internal 
consistency of the questionnaire items was examined using Cronbach alpha (with a value of 0.55 )

\section{Data analysis}

Data were presented using frequencies and percentages for categorical data and mean and standard deviation (SD) for continuous data. Knowledge and attitude questions were presented as frequencies and percentages. Questions were answered using 5-point Likert scales. For the majority of questions, strongly agree/always was assigned a score of 5 and strongly disagree/never was assigned a score of 1. A few questions were worded in the opposite direction and so scored in the opposite direction with strongly disagree/never assigned a score of 5 and strongly agree/always assigned a score of 1 (Table 1). Overall or group scores were calculated by summing the individual scores of their items (10 general questions, 7 interaction questions and overall score). Scores were then transformed into 100-point scales with $100=$ best knowledge and attitude and $20=$ worst knowledge and attitude. Significant differences in transformed scores by sociodemographic, occupations and outcome characteristics were examined using t-test or 1-way analysis of variance (ANOVA), as appropriate. Mean scores by outcome variables adjusted for significant associates were created using general linear model regression analysis. All $P$-values were 2 -tailed. $P$-value $<0.05$ was considered as significant. SPSS software, version 20.0, was used for statistical analyses.

\section{Results}

Data from 659 participants were analysed. Approximately three-quarters of the participants (74.5\%) were male and the average age was 38.2 (SD 10.0) years. More than half (54.9\%) of the participants were Saudi Arabian nationals and less than a third (30.8\%) had received medical education outside the region, in North America, western Europe or Australia. The most commonly reported monthly income $(41.5 \%)$ was between US\$2700 and US\$ 5200.

\section{Physicians' knowledge and attitudes towards pharmaceutical companies and representatives}

A total 659 participants answered the questions about knowledge and attitudes to pharmaceutical company

\begin{tabular}{|c|c|c|c|c|c|c|c|c|c|c|c|}
\hline \multirow[t]{2}{*}{ Item } & \multirow{2}{*}{$\begin{array}{l}\text { Total } \\
\text { No. }\end{array}$} & \multicolumn{2}{|c|}{ Strongly agree } & \multicolumn{2}{|c|}{ Agree } & \multicolumn{2}{|c|}{ Neutral } & \multicolumn{2}{|c|}{ Disagree } & \multicolumn{2}{|c|}{$\begin{array}{l}\text { Strongly } \\
\text { disagree }\end{array}$} \\
\hline & & No. & $\%$ & No. & $\%$ & No. & $\%$ & No. & $\%$ & No. & $\%$ \\
\hline $\begin{array}{l}\text { Accepting pharmaceutical company gifts will } \\
\text { affect my decision regarding the use of } \\
\text { certain medications or surgical instruments }\end{array}$ & 654 & 85 & 13.0 & 119 & 18.2 & 109 & 16.7 & 127 & 19.4 & 214 & 32.7 \\
\hline $\begin{array}{l}\text { Doctors in my institution accept } \\
\text { pharmaceutical company gifts }\end{array}$ & 645 & 113 & 17.5 & 219 & 34.0 & 193 & 29.9 & 82 & 12.7 & 38 & 5.9 \\
\hline $\begin{array}{l}\text { In general, the decisions of other physicians } \\
\text { regarding the use of certain medications } \\
\text { or surgical instruments are influenced after } \\
\text { receiving pharmaceutical company gifts }\end{array}$ & 648 & 53 & 8.2 & 151 & 23.3 & 237 & 36.6 & 134 & 20.7 & 73 & 11.3 \\
\hline $\begin{array}{l}\text { It is ethical to accept pharmaceutical } \\
\text { company gifts }^{\mathrm{a}}\end{array}$ & 646 & 25 & 3.9 & 80 & 12.4 & 222 & 34.4 & 151 & 23.4 & 168 & 26.0 \\
\hline $\begin{array}{l}\text { Pharmaceutical companies should be } \\
\text { banned from giving gifts to physicians }\end{array}$ & 641 & 137 & 21.4 & 142 & 22.2 & 204 & 31.8 & 112 & 17.5 & 46 & 7.2 \\
\hline $\begin{array}{l}\text { Patients should be informed about the gifts } \\
\text { given to their doctors by drug companies }\end{array}$ & 641 & 68 & 10.6 & 96 & 15.0 & 148 & 23.1 & 165 & 25.7 & 164 & 25.6 \\
\hline $\begin{array}{l}\text { Pharmaceutical sales representatives always } \\
\text { provide accurate information about their } \\
\text { new medications }{ }^{\text {a }}\end{array}$ & 647 & 42 & 6.5 & 133 & 20.6 & 206 & 31.8 & 188 & 29.1 & 78 & 12.1 \\
\hline $\begin{array}{l}\text { Receiving details from pharmaceutical sales } \\
\text { representatives increases my preference for } \\
\text { prescribing the promoted drug }\end{array}$ & 645 & 41 & 6.4 & 178 & 27.6 & 219 & 34.0 & 144 & 22.3 & 63 & 9.8 \\
\hline $\begin{array}{l}\text { Drug information from pharmaceutical sales } \\
\text { representatives influences my informed } \\
\text { decision to prescribe }\end{array}$ & 649 & 35 & 5.4 & 151 & 23.3 & 217 & 33.4 & 161 & 24.8 & 85 & 13.1 \\
\hline $\begin{array}{l}\text { Drug information from other sources is more } \\
\text { important and reliable than information } \\
\text { from pharmaceutical sales representatives }\end{array}$ & 655 & 243 & 37.1 & 199 & 30.4 & 152 & 23.2 & 45 & 6.9 & 16 & 2.4 \\
\hline
\end{tabular}

${ }^{a}$ Questions were scored in the opposite direction. 
representatives in general (Table 1). More than half $(52.1 \%)$ of the participants disagreed that accepting pharmaceutical company gifts could affect their own decisions, but a much lower percentage (32.0\%) disagreed that accepting pharmaceutical company gifts could affect the decisions of other physicians (Table 1). Only a small percentage (16.3\%) of the participants thought it was ethical to accept pharmaceutical company gifts and $43.6 \%$ agreed that pharmaceutical companies should be banned from giving gifts to physicians. More than half $(51.6 \%)$ of the participants disagreed that patients should be informed about the gifts given to their doctors by drug companies. About $41.2 \%$ of the participants disagreed that pharmaceutical sales representatives always provided accurate information about their new products. Participants were equally divided (34.0\% agree and $32.1 \%$ disagree) about whether receiving details from pharmaceutical sales representatives would increase their preference for prescribing the promoted drug. About $37.9 \%$ of the participants disagreed that drug information from pharmaceutical sales representatives influenced their decisions and the majority of the participants (67.5\%) believed that drug information from other sources was more important and reliable than from pharmaceutical sales representatives.

\section{Physicians' experiences with pharmaceutical sales representatives}

Physicians were who had ever met pharmaceutical industry representatives $(n=$ 460) answered questions about their experience of these interactions (Table 2). The majority (75.2\%) of the physicians agreed that pharmaceutical representatives frequently (usually or always) used the word "safe" when they described their products (Table 2). Less than a quarter of the participants thought that pharmaceutical representatives frequently (always or usually) mentioned the drug's interactions (19.7\%), adverse effects (20.4\%) and price (23.6\%) without being asked. The majority of the participants believed that representatives were sometimes convincing (54.4\%). The majority of the participants admitted they had frequently (29.7\%) or at least sometimes (30.8\%) been requested by representatives to try a new medicine on their patients.

\section{Mean overall knowledge and attitude scores}

The mean overall knowledge and attitude score was 63.1 [standard deviation (SD 8.5)]. Similarly, the mean score for the general questions was 62.8 (SD 10.1) and for the interaction questions was 63.0 (SD 9.1). The knowledge and attitudes scores according to participants' sociodemographic and occupational characteristics are shown on Tables 3 and 4 respectively. Since the 3 scores were very close and had the same pattern of associations with almost all the studied variables, we will restrict this description to the overall score.

There were inverse associations between the overall score and participants' age, as evidenced by the higher score with younger age and shorter work duration $(P<0.001$ for each). Participants of Saudi Arabian nationality had a significantly higher overall score than non-Saudis $(P<0.001)$. The overall score was significantly higher among

\begin{tabular}{|c|c|c|c|c|c|c|c|c|c|c|c|}
\hline \multirow[t]{2}{*}{ Item } & \multirow{2}{*}{$\begin{array}{l}\text { Total } \\
\text { No. }\end{array}$} & \multicolumn{2}{|c|}{ Always } & \multicolumn{2}{|c|}{ Usually } & \multicolumn{2}{|c|}{ Sometimes } & \multicolumn{2}{|c|}{ Rarely } & \multicolumn{2}{|c|}{ Never } \\
\hline & & No. & $\%$ & No. & $\%$ & No. & $\%$ & No. & $\%$ & No. & $\%$ \\
\hline $\begin{array}{l}\text { Pharmaceutical sales representatives use } \\
\text { the word "safe" when they describe their } \\
\text { products }\end{array}$ & 457 & 146 & 31.9 & 198 & 43.3 & 88 & 19.3 & 16 & 3.5 & 9 & 2.0 \\
\hline $\begin{array}{l}\text { Spontaneously, pharmaceutical sales } \\
\text { representatives mention the drug } \\
\text { interactions }\end{array}$ & 453 & 13 & 2.9 & 76 & 16.8 & 160 & 35.3 & 159 & 35.1 & 45 & 9.9 \\
\hline $\begin{array}{l}\text { Spontaneously, pharmaceutical sales } \\
\text { representatives mention the adverse } \\
\text { effects }^{\mathrm{a}}\end{array}$ & 456 & 20 & 4.4 & 73 & 16.0 & 168 & 36.8 & 154 & 33.8 & 41 & 9.0 \\
\hline $\begin{array}{l}\text { Spontaneously, pharmaceutical sales } \\
\text { representatives mention the price }\end{array}$ & 445 & 27 & 6.1 & 78 & 17.5 & 139 & 31.2 & 148 & 33.3 & 53 & 11.9 \\
\hline $\begin{array}{l}\text { Pharmaceutical sales representatives are } \\
\text { ready to answer my questions }{ }^{\mathrm{a}}\end{array}$ & 448 & 87 & 19.4 & 204 & 45.5 & 130 & 29.0 & 20 & 4.5 & 7 & 1.6 \\
\hline $\begin{array}{l}\text { Pharmaceutical sales representatives are } \\
\text { convincing }\end{array}$ & 447 & 28 & 6.3 & 114 & 25.5 & 243 & 54.4 & 46 & 10.3 & 16 & 3.6 \\
\hline $\begin{array}{l}\text { I receive encouragement from } \\
\text { pharmaceutical sales representatives to } \\
\text { try new medicines on my patients }\end{array}$ & 454 & 36 & 7.9 & 99 & 21.8 & 140 & 30.8 & 75 & 16.5 & 104 & 22.9 \\
\hline
\end{tabular}

${ }^{a}$ Questions were scored in the opposite direction. 
those working in public hospitals $(P$ $<0.001)$ and among those with additional income $(P<0.001)$. Participants with monthly income US\$2700-5200 had a significantly lower overall score than other groups $(P=0.024)$. There were no significant differences in the overall scores by physician's sex, medical education, clinical specialty, job rank or work history.

\section{Associations of physicians' characteristics with overall knowledge and attitude scores}

We examined the associations between the overall knowledge and attitude score and the study outcome variables. The participants with previous experience of interacting with pharmaceutical sales representatives $(n=460)$ had a higher overall mean score than those with no previous interaction $(n=199)$ [64.7 (SD 10.0) versus 62.5 (SD 7.8)] $(P=0.004)$. Similarly, the participants who did not accept pharmaceutical company gifts $(n=69)$ had a higher overall score than those who accepted them $(n=383)$ [65.2 (SD 9.0) versus $61.9(\mathrm{SD} 7.4)](P=0.001)$. Participants who reported having some type of education (lectures, workshops, etc.) about the ethics of interactions with the pharmaceutical industry ( $n$ = 341) had a slightly higher overall score than those who did not have such education $(n=289)$. However, the difference did not reach statistical significance [63.8 (SD 9.2) versus 62.8 $(\mathrm{SD} 7.7)](P=0.151)$

In multivariate analysis, adjusting for the above outcome variables as well as the variables associated with the overall score in univariate analysis (Tables 3 and 4) including age, nationality, type of hospital, working duration and additional income, it was found that refusing gifts (model coefficient $\beta=2.25, P=$ $0.037)$, having additional income $(\beta=$ $3.42, P=0.001)$ and Saudi nationality $(\beta$ $=3.37, P<0.001)$ were independently associated with a higher overall knowledge and attitude score.

\section{Discussion}

We report here the knowledge and attitudes towards the pharmaceutical industry of a group of physicians of different clinical specialties and job ranks working in Saudi Arabia and the associations with their own behaviour. The current findings showed a generally positive attitudes towards interactions with the pharmaceutical industry. Similarly, a thematic review of studies examining the attitudes and knowledge towards the pharmaceutical industry between 1996 and 2004 showed that a substantial numbers of physicians found interactions with pharmaceutical industry representatives to be appropriate, important, beneficial or ethical and felt that they should be permitted (14). Similar findings were replicated in more recent studies in developed $(2,9,15)$ and developing countries (16). Although less than half of physicians in the current study

Table 3 Mean knowledge and attitudes scores according to the sociodemographic and educational characteristics of the study physicians

\begin{tabular}{|c|c|c|c|c|c|c|}
\hline \multirow[t]{2}{*}{ Characteristic } & \multicolumn{2}{|c|}{ General questions } & \multicolumn{2}{|c|}{ Interaction questions } & \multicolumn{2}{|c|}{ All questions } \\
\hline & No. & Mean (SD) & No. & Mean (SD) & No. & Mean (SD) \\
\hline \multicolumn{7}{|l|}{ Sex } \\
\hline Male & 165 & $63.0(10.4)$ & 115 & $63.0(8.9)$ & 165 & $63.2(8.6)$ \\
\hline \multirow[t]{2}{*}{ Female } & 483 & $62.8(9.5)$ & 335 & $63.2(9.5)$ & 483 & $63.0(8.3)$ \\
\hline & & $P=0.808$ & & $P=0.838$ & & $P=0.828$ \\
\hline \multicolumn{7}{|l|}{ Age (years) } \\
\hline $20-29$ & 149 & $65.0(8.1)$ & 59 & $63.2(8.6)$ & 149 & $64.9(7.8)$ \\
\hline 30-39 & 230 & $63.2(10.9)$ & 176 & $64.2(9.0)$ & 230 & $63.7(9.1)$ \\
\hline $40-49$ & 154 & $62.3(10.8)$ & 120 & $63.1(9.5)$ & 154 & $62.6(8.9)$ \\
\hline \multirow[t]{2}{*}{$\geq 50$} & 107 & $60.1(9.6)$ & 90 & $60.4(8.8)$ & 107 & $60.2(7.3)$ \\
\hline & & $P<0.001$ & & $P=0.014$ & & $P<0.001$ \\
\hline \multicolumn{7}{|l|}{ Nationality } \\
\hline Saudi & 352 & $65.7(10.4)$ & 218 & $65.0(9.9)$ & 352 & $65.6(9.1)$ \\
\hline \multirow[t]{2}{*}{ Non-Saudi } & 289 & $59.8(8.6)$ & 227 & $61.3(7.9)$ & 289 & $60.4(6.7)$ \\
\hline & & $P<0.001$ & & $P<0.001$ & & $P<0.001$ \\
\hline \multicolumn{7}{|c|}{ Medical education $^{a}$} \\
\hline Non-local & 187 & $64.0(12.0)$ & 149 & $63.1(9.7)$ & 187 & $63.9(9.6)$ \\
\hline \multirow[t]{2}{*}{ Local } & 421 & $62.9(9.4)$ & 272 & $63.6(8.9)$ & 421 & $63.3(8.1)$ \\
\hline & & $P=0.211$ & & $P=0.570$ & & $P=0.483$ \\
\hline
\end{tabular}

${ }^{a}$ Non-local: North America, western Europe or Australia; local: Saudi Arabia or elsewhere in the Middle East. $S D=$ standard deviation . 


\begin{tabular}{|c|c|c|c|c|c|c|}
\hline \multirow[t]{2}{*}{ Characteristics } & \multicolumn{2}{|c|}{ General questions } & \multicolumn{2}{|c|}{ Interaction questions } & \multicolumn{2}{|c|}{ All questions } \\
\hline & No. & Mean (SD) & No. & Mean (SD) & No. & Mean (SD) \\
\hline \multicolumn{7}{|l|}{ Type of hospital } \\
\hline Public & 471 & $63.9(10.1)$ & 304 & $63.9(9.2)$ & 471 & $64.1(8.6)$ \\
\hline Private & 111 & $59.1(8.6)$ & 99 & $61.2(7.9)$ & 111 & $59.8(6.9)$ \\
\hline \multirow[t]{2}{*}{ Both } & 50 & $62.1(11.9)$ & 47 & $61.5(9.2)$ & 50 & $62.2(9.0)$ \\
\hline & & $P<0.001$ & & $P=0.016$ & & $P<0.001$ \\
\hline \multicolumn{7}{|l|}{ Clinical specialty } \\
\hline Psychiatry & 114 & $63.9(10.2)$ & 89 & $64.6(8.8)$ & 114 & $64.6(8.9)$ \\
\hline Family medicine & 78 & $64.0(12.0)$ & 62 & $65.7(9.3)$ & 78 & $64.5(9.6)$ \\
\hline Surgery & 70 & $61.8(10.9)$ & 49 & $64.1(9.3)$ & 70 & $62.2(8.2)$ \\
\hline Internal medicine & 75 & $62.9(9.4)$ & 53 & $59.7(9.8)$ & 75 & $61.9(7.5)$ \\
\hline Paediatrics & 60 & $61.0(9.0)$ & 49 & $65.3(7.9)$ & 60 & $62.4(7.5)$ \\
\hline Orthopaedics & 42 & $61.1(8.4)$ & 33 & $61.7(9.7)$ & 42 & $61.4(7.0)$ \\
\hline \multirow[t]{2}{*}{ Other } & 198 & $62.4(9.2)$ & 116 & $61.2(8.0)$ & 198 & $62.6(8.0)$ \\
\hline & & $P=0.357$ & & $P<0.001$ & & $P=0.094$ \\
\hline \multicolumn{7}{|l|}{ Job rank } \\
\hline Consultant & 175 & $63.6(12.4)$ & 136 & $64.1(9.7)$ & 175 & $63.8(10.4)$ \\
\hline Specialist/registrar & 187 & $61.6(10.0)$ & 154 & $62.7(8.9)$ & 187 & $62.1(7.9)$ \\
\hline Resident/intern & 226 & $63.6(8.1)$ & 121 & $62.2(8.6)$ & 226 & $63.5(7.3)$ \\
\hline \multirow[t]{2}{*}{ Other } & 14 & $62.2(13.0$ & 10 & $59.4(6.6)$ & 14 & $62.2(11.0)$ \\
\hline & & $P=0.158$ & & $P=0.198$ & & $P=0.248$ \\
\hline \multicolumn{7}{|l|}{ Work duration (years) } \\
\hline $0-9$ & 294 & $64.1(9.5)$ & 166 & $64.0(8.8)$ & 294 & $64.3(8.4)$ \\
\hline $10-19$ & 193 & $62.7(11.4)$ & 158 & $63.6(9.6)$ & 193 & $63.1(9.4)$ \\
\hline $20-29$ & 113 & $61.2(9.4)$ & 90 & $61.0(8.5)$ & 113 & $61.0(7.0)$ \\
\hline \multirow[t]{2}{*}{$\geq 30$} & 39 & $58.3(9.2)$ & 35 & 61.7 (9.3) & 39 & $59.5(7.3)$ \\
\hline & & $P<0.001$ & & $P=0.058$ & & $P<0.001$ \\
\hline \multicolumn{7}{|l|}{ Monthly income (US\$) } \\
\hline$<2700$ & 107 & $63.8(8.2)$ & 39 & $59.8(6.8)$ & 107 & $63.4(7.2)$ \\
\hline $2700-5200$ & 266 & $61.7(9.4)$ & 196 & $62.3(8.3)$ & 266 & $62.2(7.6)$ \\
\hline $5300-7900$ & 110 & $62.5(10.4)$ & 83 & $64.3(9.6)$ & 110 & $63.5(9.5)$ \\
\hline \multirow[t]{2}{*}{$\geq 8000$} & 158 & $65.2(11.9$ & 130 & $64.2(10.2)$ & 158 & 64.8 (9.9) \\
\hline & & $P=0.005$ & & $P=0.019$ & & $P=0.024$ \\
\hline \multicolumn{7}{|l|}{ Additional income $^{a}$} \\
\hline No & 509 & $62.2(9.7)$ & 352 & $62.5(8.8)$ & 509 & $62.5(8.2)$ \\
\hline \multirow[t]{2}{*}{ Yes } & 143 & $65.4(11.3)$ & 103 & $65.0(9.6)$ & 143 & $65.2(9.2)$ \\
\hline & & $P<0.001$ & & $P=0.013$ & & $P<0.001$ \\
\hline \multicolumn{7}{|l|}{ Work history } \\
\hline Non-local & 119 & $62.8(10.6)$ & 97 & 63.7 (8.3) & 119 & $63.3(8.5)$ \\
\hline \multirow[t]{2}{*}{ Local } & 482 & $63.3(10.1)$ & 316 & 63.5 (9.4) & 482 & $63.6(8.7)$ \\
\hline & & $P=0.608$ & & $P=0.860$ & & $P=0.756$ \\
\hline
\end{tabular}

${ }^{a}$ Additional income income obtained from outside the hospital due to academic, medical or non-medical activities.

${ }^{b}$ Non-local: work experience in North America, western Europe or Australia; local: worked in Saudi Arabia or Middle East. $S D=$ standard deviation .

supported banning pharmaceutical company gifts and only a quarter supported disclosing received gifts to their patients, the majority of them did not find it ethical to accept pharmaceutical company gifts. This may reflect a limited awareness of the impact of interactions or unacknowledged bias due to conflicts of interest (17). 
Despite data that has linked accepting gifts to the prescribing behaviour of physicians (12), the influence on clinical decisions is often unacknowledged by many physicians who believe they can adequately evaluate and filter information presented to them by pharmaceutical sales representatives $(14,17)$. Physicians in the current study tended to ignore the impact of accepting pharmaceutical company gifts and receiving details from pharmaceutical sales representatives on their own clinical decisions. Interestingly, they also underestimated the influence on themselves compared with their colleagues. Similarly, a number of studies showed that physicians and nurses believed they are more immune to industry influence than their colleagues are $(14,15,18)$. As in other studies in developed and developing countries, the majority of physicians in the current study had doubts about the accuracy of drug safety information provided by pharmaceutical sales representatives $(16,19,20)$. Supporting our finding about physicians' trust in non-pharmaceutical representative sources, it has been shown that physicians believed that practice guidelines, peer-reviewed evidence and opinions of local physician experts are important counterweights to the influence of pharmaceutical sales representatives (21).

The knowledge and attitude scores in the current study were transformed into 100-point scales for easy interpretation. Since the overall score was 63 , this may roughly indicate a suboptimal level of information among the studied physicians. Although we have reported some sociodemographic, occupational and behavioural factors significantly associated with knowledge and attitudes, the absolute differences rarely exceeded 5 points. However, these small differences between factor groups were the average of much bigger differences in individual questions, sometimes in opposite directions. For example, those who accepted gifts were $50 \%$ less likely to believe that gift acceptance was unethical but 15\% more likely to deny the influence on their decisions.

As expected, better knowledge and attitudes about interactions with the pharmaceutical industry in the current study were associated with refusal of pharmaceutical company gifts. This may indicate the importance of good knowledge and correct attitudes about interactions with the pharmaceutical industry. It has been shown that education and discussion about the ethical issues related to exposure to pharmaceutical representatives can improve the attitudes of residents and medical students towards interactions (22-25). Interestingly,knowledge and attitudes about interactions with the pharmaceutical industry in the current study was not significantly associated with having received ethics education. While this may be difficult to explain, it may simply indicate inadequate or insufficient ethics education offered to the studied physicians. These educational activities were predominantly in the form of lectures, limiting the role of more interactive educational activities. It has been shown that active learning strategies such as brainstorming sessions, role plays and group activities were effective in improving the knowledge, attitudes and skills of medical students about pharmaceutical promotion (26).

The current study had many advantages: bridging the local knowledge gap about attitudes towards interactions with pharmaceutical industry, surveying a relatively large number of physicians across several specialties and linking the knowledge and attitudes with behaviours. Nevertheless, we acknowledge a number of limitations. Being based on a convenience sample, the results should be generalized with caution and should not be regarded as representative of all physicians working in Saudi hospitals.
Being a self-reported study, the possibility of reporting bias concerning attitudes or underestimation of interactions with the pharmaceutical industry cannot be excluded. The questionnaire in its final version had a poor indicator for internal consistency of its items (as indicated by an overall Cronbach alpha value of $0.55)$. Therefore, the reliability of the questionnaire can be doubted and the findings should be interpreted with caution, reflecting the need of a standard questionnaire to assess physicians' attitudes towards the pharmaceutical industry.

In conclusion, we report suboptimal knowledge and a generally positive attitude towards the pharmaceutical industry among a group of physicians working in Saudi Arabia. As the majority of physicians were in the habit of accepting gifts, the majority found it ethical to interact with the pharmaceutical industry representatives and tended to overlook any potential influences on clinical decision-making. Better knowledge and attitudes in the current study were independently associated with refusal of pharmaceutical company gifts, additional income and Saudi nationality. Improving the knowledge and attitudes of physicians may reduce the frequency of their interactions and influences from the pharmaceutical industry. Active learning strategies about appropriate industry interactions and awareness of local governing policies should be included in medical school curricula and residency training programmes.

\section{Acknowledgements}

Funding: The authors would like to extend their sincere appreciation to the Deanship of Scientific Research at King Saud University for funding this research group (No. RG-1435-087).

Competing interests: None declared. 


\section{References}

1. Campbell EG, Gruen RL, Mountford J, Miller LG, Cleary PD, Blumenthal D. A national survey of physician-industry relationships. N Engl J Med. 2007 Apr 26;356(17):1742-50. PMID:17460228

2. Saito S, Mukohara K, Bito S. Japanese practicing physicians' relationships with pharmaceutical representatives: a national survey. PLoS One. 2010;5(8):e12193. PMID:20730093

3. McNeill PM, Kerridge IH, Henry DA, Stokes B, Hill SR, Newby $D$, et al. Giving and receiving of gifts between pharmaceutical companies and medical specialists in Australia. Intern Med J. 2006 Sep;36(9):571-8. PMID:16911549

4. Komesaroff PA. Ethical issues in the relationships with industry: an ongoing challenge. New guidelines open for public comment. J Paediatr Child Health. 2005 Nov;41(11):558-60. PMID:16398836

5. Brennan TA, Rothman DJ, Blank L, Blumenthal D, Chimonas SC, Cohen JJ, et al. Health industry practices that create conflicts of interest: a policy proposal for academic medical centers. JAMA. 2006 Jan 25;295(4):429-33. PMID:16434633

6. Marco CA, Moskop JC, Solomon RC, Geiderman JM, Larkin GL. Gifts to physicians from the pharmaceutical industry: an ethical analysis. Ann Emerg Med. 2006 Nov;48(5):513-21. PMID:17052550

7. Chren MM, Landefeld CS, Murray TH. Doctors, drug companies, and gifts. JAMA. 1989 Dec 22-29;262(24):3448-51. PMID:2585690

8. Chimonas S, Rozario NM, Rothman DJ. Show us the money: lessons in transparency from state pharmaceutical marketing disclosure laws. Health Serv Res. 2010 Feb;45(1):98-114. PMID:19840133

9. Korenstein D, Keyhani S, Ross JS. Physician attitudes toward industry: a view across the specialties. Arch Surg. 2010 Jun;145(6):570-7. PMID:20566978

10. Castresana L, Mejia R, Aznar M. Actitud de los medicos frente a las practicas de promocion de la industria farmaceutica. [The attitude of physicians regarding the promotion strategies of the pharmaceutical industry]. Medicina (B Aires). 2005;65(3):247-51. PMID:16042137

11. Moubarak G, Martins RP, Zuily S, Mechulan A, Hariri S, Guiot A. Attitudes of cardiology residents toward interactions with the pharmaceutical industry. Int J Cardiol. 2011 Feb 3;146(3):461-2. PMID:21122930

12. Spurling GK, Mansfield PR, Montgomery BD, Lexchin J, Doust J, Othman N, et al. Information from pharmaceutical companies and the quality, quantity, and cost of physicians' prescribing: a systematic review. PLoS Med. 2010 Oct;7(10):e1000352. PMID:20976098

13. Almalki M, Fitzgerald G, Clark M. Health care system in Saudi Arabia: an overview. East Mediterr Health J. 2011 Oct;17(10):784-93. PMID:22256414

14. Zipkin DA, Steinman MA. Interactions between pharmaceutical representatives and doctors in training. A thematic review. J Gen Intern Med. 2005 Aug;20(8):777-86. PMID:16050893
15. Jutel A, Menkes DB. "But doctors do it...": nurses' views of gifts and information from the pharmaceutical industry. Ann Pharmacother. 2009 Jun;43(6):1057-63. PMID:19470854

16. Ben Abdelaziz A, et al. [Attitudes of general practitioners to pharmaceutical sales representatives in Sousse] [in Arabic]. East Mediterr Health J. 2003 Sep-Nov;9(5-6):1075-83. PMID:16450540

17. Fischer MA, Keough ME, Baril JL, Saccoccio L, Mazor KM, Ladd E, et al. Prescribers and pharmaceutical representatives: why are we still meeting? J Gen Intern Med. 2009 Jul;24(7):795801. PMID:19424764

18. Vancelik S, Beyhun NE, Acemoglu H, Calikoglu O. Impact of pharmaceutical promotion on prescribing decisions of general practitioners in Eastern Turkey. BMC Public Health. 2007;7:122. PMID:17592644

19. Othman N, Vitry Al, Roughead EE, Ismail SB, Omar K. Medicines information provided by pharmaceutical representatives: a comparative study in Australia and Malaysia. BMC Public Health. 2010;10:743. PMID:21118551

20. Mintzes B, Lexchin J, Sutherland JM, Beaulieu MD, Wilkes MS, Durrieu G, et al. Pharmaceutical sales representatives and patient safety: a comparative prospective study of information quality in Canada, France and the United States. J Gen Intern Med. 2013 Oct;28(10):1368-75. PMID:23558775

21. Naik AD, Woofter AL, Skinner JM, Abraham NS. Pharmaceutical company influence on nonsteroidal anti-inflammatory drug prescribing behaviors. Am J Manag Care. 2009 Apr;15(4):e9-15. PMID:19341315

22. Hopper JA, Speece MW, Musial JL. Effects of an educational intervention on residents' knowledge and attitudes toward interactions with pharmaceutical representatives. J Gen Intern Med. 1997 Oct;12(10):639-42. PMID:9346461

23. Kao AC, Braddock C 3rd, Clay M, Elliott D, Epstein SK, Filstead $W$, et al. Effect of educational interventions and medical school policies on medical students' attitudes toward pharmaceutical marketing practices: a multi-institutional study. Acad Med. 2011 Nov;86(11):1454-62. PMID:21952057

24. Wofford JL, Ohl CA. Teaching appropriate interactions with pharmaceutical company representatives: the impact of an innovative workshop on student attitudes. BMC Med Educ. 2005 Feb 8;5(1):5. PMID:15698480

25. Kelcher S, Brownoff R, Meadows LM. Structured approach to pharmaceutical representatives. Family medicine residency program. Can Fam Physician. 1998 May;44:1053-6, 1059-60. PMID:9612591

26. Shankar PR, Singh KK, Piryani RM. Knowledge, attitude and skills before and after a module on pharmaceutical promotion in a Nepalese medical school. BMC Res Notes. 2012;5:8. PMID:22221485 